Neth. J. PI. P'ath. 97 (1991) 55-61

\title{
Modelling the escape of Chondrostereum purpureum spores from a larch forest with biological control of Prunus serotina
}

\author{
MEINDERT D. DE JONG', PATRICIA S. WAGENMAKERS ${ }^{2}$ and J. GOUDRIAAN ${ }^{3}$
}

1 Centre for $\wedge$ grobiological Research (CABO), P.O. Box 14, 6700 AA Wageningen, the Netherlands; present address: Tarthorst 195, $6708 \mathrm{HJ}$ Wageningen, the Netherlands

2 Research Station for Fruit Growing, Brugstraat 51, 4475 AN Wilhelminadorp, the Netherlands

3 Theoretical Production Ecology, Agricultural University, P.O. Box 14, 6700 AA Wageningen, the Netherlands

Accepted 25 October 1990

\begin{abstract}
Chondrostereum purpureum is being developed as a microbial herbicide to control Prunus serotina in coniferous forests. After biological control, the fungus produces basidiospores that may reach and infect non-target plants. As part of a risk analysis, spore escape from a forest was quantified. For this purpose, a stratified model was developed for a forest of $250 \mathrm{~m}$ with $250 \mathrm{~m}$. A turbulent diffusion equation was used to describe spore fluxes for each layer.

In a simple calculation procedure, the spore fluxes for the different layers were calculated simultaneously. The downwind escape fraction was found to vary from 0.19 to 0.45 , and the upward escapte fraction from 0.07 to 0.23 . These escape fractions increased with increasing wind speed.

Number of spores released from basidiocarps, and escape fractions could be used as inputs for a Gaussian plume model to calculate spore immission into orchards.
\end{abstract}

Additional keywords: simulation, spore dispersal, turbulent diffusion model.

\section{Introduction}

Chondrostereum purpureum is potentially useful as a biological control agent of Prunus serotina (black cherry). Prunus serotina is an introduced tree species in the $\mathrm{Ne}$ therlands, but it has become a pest in many coniferous forests (Scheepens and Hoogerbrugge, 199()). It can be controlled by applying a suspension of fragmented mycelium on freshly cut tree stubs, so that the use of herbicides can be avoided (De Jong, 1989). However, Chondrostereum purpureum is also the cause of silverleaf disease on fruit trees, which are particularly susceptible after pruning. During autumn following the treatment of the black cherry trees, basisdiospores are produced on the treated stubs. The spores are dispersed by wind and may infect fruit trees even at considerable distance from the forest.

A risk analysis was made of the events leading to infection of non-target plants (De Jong, 1988; De Jong et al., 1990a, b). In this paper, we describe a theoretical approach 
to simulate spore dispersal within and out of a forest, in order to calculate the fraction of spores escaping from the forest.

Dispersal of airborne spores has been simulated for many causal agents of crop diseases (e.g. Legg and Powell, 1979; Aylor and Taylor, 1983; Aylor and Ferrandino, 1985; McCartney, 1987). Di-Giovanni et al. (1989) modelled dispersion of tree pollen within a forest canopy. In all these studies, dispersal of particles was described with a mathematical model. In our study, we used a turbulent diffusion model (K-type model) similar to that of McCartney and Fitt (1985).

\section{Materials and methods}

Within a forest with biological control of black cherry, the density of released $C$. purpureum spores $(C)$ depends on air streamings, deposition, and sedimentation. McCartney and Fitt (1985) extensively describe the diffusion equation for these processes. Assuming that the rate of spore release from basidiocarps is continuous and constant, a steady state is reached within a few hundreds of seconds of time. Spore concentration $C$ is then in equilibrium with input of spores from basidiocarps on one hand, and losses by vertical turbulent transport, by sedimentation, and by deposition on the other. To explain the procedure, the equation for a single layer is given first. Assuming zero concentration of spores in the external air, the equation for a layer with height $h$ is:

$$
u \frac{h C}{x_{\mathrm{f}}}=Q+K \frac{\mathrm{d} C}{\mathrm{~d} z}-v_{\mathrm{s}} C-v_{\mathrm{d}} C A_{\mathrm{d}}
$$

with $u=$ wind speed within in the layer ( $\left.\mathrm{m} \mathrm{s}^{-1}\right), h=$ height (thickness) of the layer $(\mathrm{m}), C=$ spore density (spore $\left.\mathrm{m}^{3}\right), x_{\mathrm{r}}=$ downwind length of the forest $(\mathrm{m}), Q=$ release rate of spores per ground area (spores $\left.\mathrm{m}^{-2} \mathrm{~s}^{-1}\right), K=$ turbulent diffusion coefficient $\left(\mathrm{m}^{2} \mathrm{~s}^{-1}\right), z=$ height (vertical dimension) $(\mathrm{m}), v_{\mathrm{s}}=$ sedimentation velocity $(\mathrm{m}$ $\left.\mathrm{s}^{-1}\right), v_{\mathrm{d}}=$ deposition velocity $\left(\mathrm{m} \mathrm{s}^{-1}\right), A_{\mathrm{d}}=$ deposition-area density $\left(\mathrm{m}^{2} \mathrm{~m}^{-2}\right)$.

The left hand term $u\left(h C / x_{i}\right)$ describes the rate of downwind horizontal loss. When it is divided by the production rate $Q$, the downwind escape fraction $E_{\mathrm{h}}$ is found. The upward (vertical) flux is found as the term $K(\mathrm{~d} C / \mathrm{d} z)$ and when it is divided by $Q$ the escape fraction $E_{\mathrm{v}}$ is found. The other two terms concern sedimentation with velocity $v_{\mathrm{s}}$ towards the soil surface, and deposition with velocity $v_{\mathrm{d}}$ onto leaves, branches and again soil surface.

To solve Equation 1, $K(\mathrm{~d} C / \mathrm{d} z)$ is approximated by $-K C /(0.5 h)$, so that the whole expression van be solved for $C$.

To allow for the considerable vertical gradient in spore density that may exist, the model was extended in four horizontal layers (Fig. 1). Only the bottom layer contained spore releasing stubs, and so the source term $Q$ was zero for the upper three layers. Wind speed and turbulent diffusion coefficient for each layer were calculated first from the wind speed $u_{\mathrm{r}}$ at $25 \mathrm{~m}$ height above the forest (Goudriaan, 1977, 1979). The vertical flux equation $K(\mathrm{~d} C / \mathrm{d} z)$ was applied for lower and upper side of each layer to represent exchange between adjacent layers, and was rewritten as a finite difference equation of the type $\left(C_{\mathrm{i}}-C_{\mathrm{i}},{ }_{1}\right) K /(\Delta z)$. A fully explicit solution was found by solving the equations for the diffusion fluxes for each layer using matrix inversion 


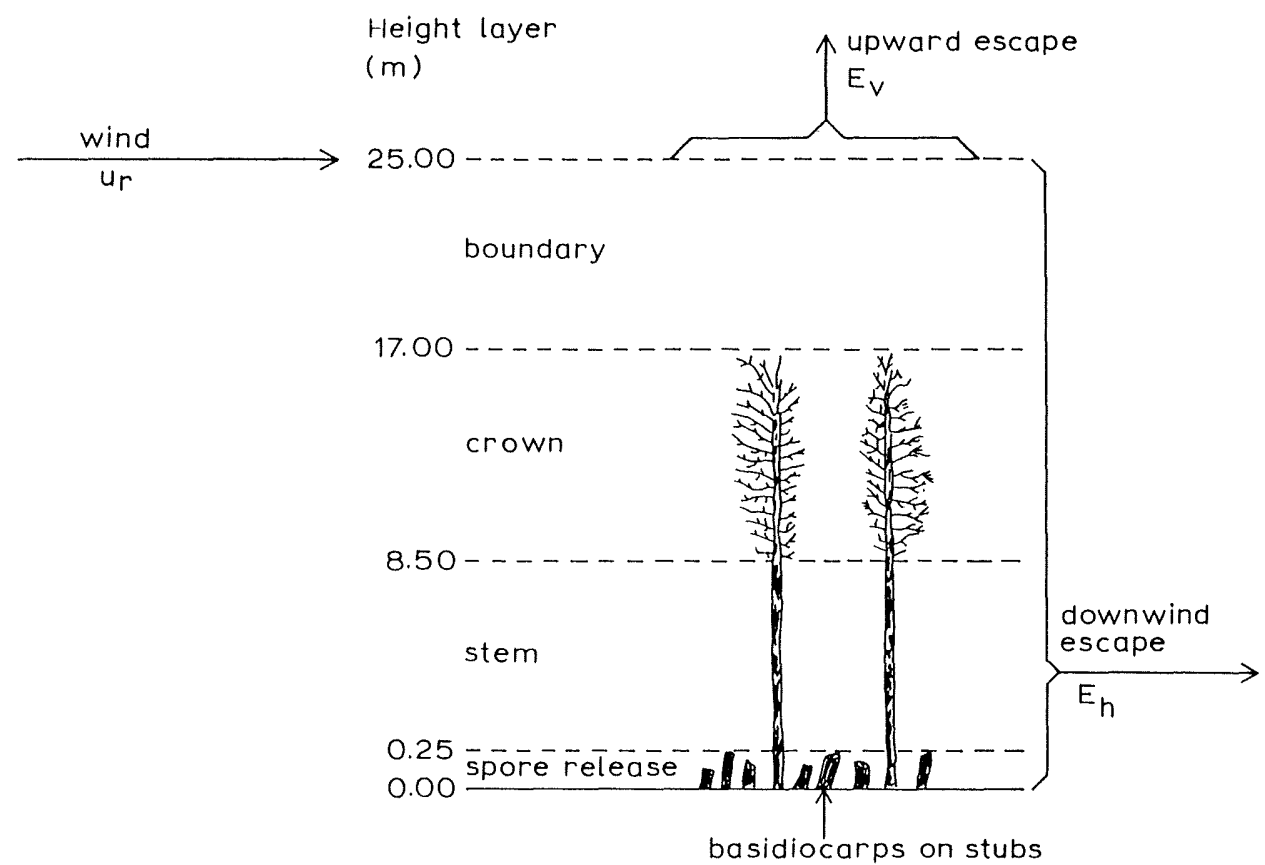

Fig. 1. Modelled partitioning of a larch forest in horizontal layers. Spore producing basidiocarps of Chondrostereum purpureum are only present in the bottom layer on stubs of Prunus serotina. Two escape routes (upward and downwind) of spores are shown.

(Waggoner et al., 1969; Van der Werf et al., 1989; Ward et al., 1989). With this method, the steady state concentration for each of the four layers could be found instantaneously.

Basidiospores of $C$. purpureum measure approximately 4 to $6 \mu \mathrm{m}$. The sedimentation velocity was calculated on basis of Stokes' law, yielding $v_{\mathrm{s}}=0.001 \mathrm{~m} \mathrm{~s}^{-1}$. This sedimentation velocity determines the rate of settling of spores towards the soil surface. Quantitatively, deposition of spores on leaves, branches and on low vegetation is much more important. This deposition process is determined by catchment of spores moving with the wind and impacting on obstacles such as leaves and branches. A mean value for deposition velocity $v_{\mathrm{d}}$ was assumed to be $0.01 \mathrm{~m} \mathrm{~s}^{-1}$. This value is based on measurements in,forests (Raynor et al., 1974, 1975), or in wind tunnels with particles of similar size (Little, 1977; Chamberlain and Little, 1981). The deposition-area index $\left(A_{\mathrm{d}}\right)$ was estimated in the experimental larch forest at $20 \mathrm{~km}$ distance from Wageningen as an 'area-index'. The 'area-indices' of larch needles and branches were estimated to be 2.0 , and $1.8 \mathrm{~m}^{2} \mathrm{~m}^{-2}$, respectively. For area index of the forest floor by definition the value 1 was taken. For a typical situation the release rate $Q$ was 5 spores $\mathrm{m}^{-2}$ $\mathrm{s}^{-1}$ in the spore release layer. The value of this parameter was based on measurements of spore release at the experimental site (De Jong, 1988), and on simulation of spore liberation as a function of temperature according to indoor measurements (Grosclaude, 1969; Spiers, 1985). The value of $x_{\mathrm{r}}$ was $250 \mathrm{~m}$.

Neth. J. Pl. Path. 97 (1991) 
Hourly means of spore densities were measured at $0.25 \mathrm{~m}$ height in the experimental larch forest in the autumn, using a Burkard spore trap. Wind speed at $2 \mathrm{~m}$ height in the larch forest was recorded by a cup anemometer during 1920 hours. Wind speeds at $2 \mathrm{~m}$ height in the model forest were calculated from wind speeds at $25 \mathrm{~m}$ height $\left(u_{25}\right)$ at the Meteorological Station Wageningen with help of the microweather model. Calculated values of spore densities and wind speeds were compared with measured values in the larch forest.

\section{Results}

Measured and calculated wind speeds were in good agreement in $90 \%$ of the considered hours. Calculated spore densities decrease with higher wind speed (Table 1). Spore densities measured in the experimental larch forest decreased from 774 spores $\mathrm{m}^{-3}$ in October to 219 spores $\mathrm{m}^{3}$ in December. The hourly spore densities ranged from nearly nil (with frost) to more than 1000 spores $\mathrm{m}^{3}$ (after heavy rain and with high temperature). Spore production in the basidiocarps at the experimental site varied enormously. Spore density is related to spore production. Measured and calculated values of spore density $(C)$ were in reasonable agreement; they were ususally both of the same order of magnitude.

The partitioning of spore losses into fractions escaped $\left(E_{\mathrm{h}}, E_{\mathrm{v}}\right)$, sedimented and deposited to soil $D_{\mathrm{s}}$, to branches $D_{\mathrm{b}}$, and to needles $D_{11}$ are given in Table 1 . By definition (and as a model balance check) their sum equals unity.

The fraction $D_{\text {s }}$ given in Table 1 includes also sedimentation which was normally negligible in comparison with the other fluxes anyway. In the spore release layer, sedimentation rate was small compared to deposition rate. Only at very low windspeeds $\left(u_{\mathrm{r}}<0.5 \mathrm{~m} \mathrm{~s}^{-1}\right)$ began sedimentation to play some role. Deposition was important, and so the value of deposition velocity and of deposition area ('area-index') had a large effect on spore density $C$, and on the partitioning of spore production over deposition escape fractions.

A further refinement of the number of layers from 4 to 31 had hardly an effect on the output of the model. However, a one-layer model of the forest was too simplistic (Van der Werf et al., 1988).

Wind speed $u_{\mathrm{r}}$ strongly influenced spore density, escape, and deposition (Table 1). The downwind escape fraction varied from 0.19 to 0.47 , and the upward escape fraction from 0.07 to 0.23 . Most of the transport took place in the stem layer. Deposition on the soil was about ten times larger than deposition on needles and branches in the

Table 1. Calculated spore densitics at $0.25 \mathrm{~m}$ height in a larch forest (see Fig. 1), downwind $\left(E_{\mathrm{h}}\right)$ and upward escape fractions $\left(E_{\mathrm{v}}\right)$, deposition fractions on soil $\left(D_{\mathrm{s}}\right)$, branches $\left(D_{\mathrm{b}}\right)$, and needles $\left(D_{\mathrm{n}}\right)$ for a few wind specds at $25 \mathrm{~m}$ height $\left(u_{\mathrm{r}}\right)$.

\begin{tabular}{lllllll}
\hline $\begin{array}{l}u_{\mathrm{r}} \\
\left(\mathrm{m} \mathrm{s}^{-1}\right)\end{array}$ & $\begin{array}{l}C \\
\left(\text { spores m }{ }^{-3}\right)\end{array}$ & $E_{\mathrm{ll}}$ & $E_{\mathrm{v}}$ & $D_{\mathrm{s}}$ & $D_{\mathrm{b}}$ & $D_{\mathrm{n}}$ \\
1.5 & 313 & & & & & \\
4.0 & 184 & 0.19 & 0.07 & 0.65 & 0.05 & 0.05 \\
8.0 & 111 & 0.36 & 0.17 & 0.39 & 0.04 & 0.04 \\
\hline
\end{tabular}


crown layer. Sedimentation of $C$. purpureum spores played a negligible role in this model. Downwind and upward escape fractions increased with increasing wind speed $\left(u_{r}\right)$, while deposition fractions decreased (Table 1).

\section{Discussion}

The maximum emission rate of a forest with biological control can be estimated by multiplication of fructification, sporulation reate, and escape fraction. At the experimental sitc, $0.75 \mathrm{stubs} \mathrm{m}^{2}$ were counted, each of them with $6 \mathrm{~cm}^{2}$ of basidiocarps on average. Sporulation rate is related to temperature. At $15^{\circ} \mathrm{C}$, it reaches a maximum of 176 spores $\mathrm{cm}^{2} \mathrm{~s}{ }^{1}$ (Grosclaude, 1969; Spiers, 1985). In the model forest, the sum of escape in upward and downwind directions reached its calculated maximum at $u_{25}=8 \mathrm{~m} \mathrm{~s}^{-}$. Maximal emission for the experimental site, if under full biological control, can now be estimated as follows:

$$
\left(6 * 0.75 * 250^{2}\right) * 176 *(0.47+0.23)=3010^{6} \text { spores }^{-1}
$$

This rate is more than ten times higher than the rate that was found in the typical situation presented before, but such a high rate could be used in a risk assessment study.

To solve the equations we used a steady state approach instead of solving the dynamic partial differential equations as Legg and Powell (1979), and Rijsdijk and Rappoldt (1979) did. In this way, a relatively simple calculation procedure written in FORTRAN sufficed. This method reduced computation time more than 20 -fold.

We concluded from a sensitivity analysis that the value of the deposition velocity, and the deposition-area-index of the forest floor are important factors to consider in modelling spore dispersal within a forest. Wind speed as a driving force is extremely important. It is, however, quite difficult to model wind speeds at different heights within a forest from the actual leaf canopy profile. An empirical solution based on measurements of wind speed within forests (Allen, 1968; Raynor, 1971) is probably more satisfying.

Sometimes (in 3\% of the considered hours), a thermal inversion layer was found within or just above the forest (De Jong, 1988; De Jong et al., 1990b). Under such conditions no upward escape will occur.

On the other hand, the upward escape fraction will probably be larger than the one modelled here if wind and turbulence have a strongly intermittent ('gusty') character. In such a weather condition, calm periods of a few minutes are interrupted by wind gusts during which most of the transport occurs (Goudriaan, 1989; Aylor, 1990). This type of transport was not studied here, but it deserves further attention.

The emission from the forest may be used as input for a Gaussian plume model. The Gaussian plume model, commonly used to predict air pollution concentration, may also be used to predict mean density of $C$. purpureum spores at various distances from a forest with biological control of $P$. serotina. Approximation of a forest by an imaginary point source suffices for this purpose (De Jong, 1988), even with the dimensions of the model forest $\left(250^{2} \mathrm{~m}^{2}\right)$. Accordingly, the emission model can be linked to the Gaussian plume model to perform a risk analysis (De Jong, 1988; De Jong et al., 1990a, b). 


\section{Acknowledgements}

Thanks are due to dr P.C. Scheepens (Centre for Agrobiological Research) for valuable criticism and services with preparation of the manuscript. Professor dr R. Rabbinge (Theoretical Production Ecology) has critically read the manuscript.

\section{References}

Allen, L.H., 1968. Turbulence and wind speed spectra within a Japanese larch plantation. Journal of Applied Meterology 7: 73-78.

Aylor, D.E., 1990. The role of intermittent wind in the dispersal of fungal pathogens. Annual Review of Phytopathology 28: 73-92.

Aylor, D.E. \& Ferrandino, F.J., 1985. Escape of urediniospores of Uromyces phaseoli from a bean field canopy. Phytopathology 75: 1232-1235.

Aylor, D.E. \& Taylor, G.S., 1983. Escape of Peronospora tabacina spores from a field of diseased tobacco plants. Phytopathology 73: 525-529.

Chamberlain, A.C. \& Little, P., 1981. Transport and capture of particles by vegetation. In: J. Grace, E.D. Ford \& P.G. Jarvis (Eds), Plants and their atmospheric environment, pp. 147-173. Blackwell Scientific Publications, Oxford.

De Jong, M.D., 1988. Risico voor fruitbomen en inheemse bomen na bestrijding van Amerikaanse vogelkers (Prunus serotina) met loodglansschimmel (Chondrostereum purpureum). Thesis, Agricultural University, Wageningen, $138 \mathrm{pp}$. Appendix: Computer programs for spore dispersal of Chondrostereum purpureum within and outside a larch forest, $37 \mathrm{pp}$.

De Jong, M.D., 1989. Biologische bestrijding van Amerikaanse vogelkers in Limburg. Natuurhistorisch Maandblad 78: 126-130.

De Jong, M.D., Scheepens, P.C. \& Zadoks, J.C., 1990a. Risk analysis for biological control: A Dutch case study in biocontrol of Prunus serotina by the fungus Chondrostereum purpureum. Plant Disease 74: 189-194.

De Jong, M.D., Scheepens, P.C. \& Zadoks, J.C., 1990b. Risk analysis applied to biological control of a forest weed, using the Gaussian plume model. Grana 29: 139-145.

Di-Giovanni, F., Beckett, P.M. \& Filenley, J.R., 1989. Modelling of dispersion and deposition of tree pollen within a forest canopy. Grana 28: 129-139.

Goudriaan, J., 1977. Crop micrometcorology: a simulation study. Pudoc, Wageningen, 249 pp.

Goudriaan, J., 1979. Microweather simulation model, applied to a forest. In: S. Haldin (Ed.): Comparison of forest water and energy exchange models, pp. 47-57. International Society for Ecological Modelling, Copenhagen.

Goudriaan, J., 1989. Simulation of micrometeorology of crops, some methods and their problems, and a few results. Agricultural and Forest Meteorology 47: 239-258.

Grosclaude, C., 1969. Le plomb des arbres fruitiers. VII. Observations sur les carpophores et les spores du Stereum purpureum. Annales de Phytopathologie 1: 75-85.

Legg, B.J. \& Powell, F.A., 1979. Spore dispersal in a barley crop: a mathematial model. Agricultural Meteorology 20: 47-67.

Little, P., 1977. Deposition of 2.75, 5.0 and $8.5 \mu \mathrm{m}$ particles to plant and soil surfaces. Environmental Pollution 12: 293-305.

McCartney, H.A., 1987. Deposition of Erisyphe graminis conidia on a barley crop. II. Consequences for spore dispersal. Journal of Phytopathology 118: 258-264.

McCartney, H.A. \& Fitt, B.D.L., 1985. Construction of dispersal models. Advances in Plant Pathology 3: 107-143.

Raynor, G.S., 1971. Wind and temperature structure in a coniferous forest and a contiguous field. Forest Science 17: 351-363.

Raynor, G.S., Hayes, J.V. \& Ogden, E.C., 1974. Particulate dispersion into and within a forest. 
Boundary Layer Meteorology 7: 429-456.

Raynor, G.S., Hayes, J.V. \& Ogden, E.C., 1975. Particulate dispersion from sources within a forest. Boundary Layer Meteorology 9: 257-277.

Rijsdijk, F.H. \& Rappoldt, K., 1979. A model of spore dispersal inside and above canopies. Proceedings 1st International Conference on Aerobiology, 1978: 407-410.

Scheepens, P.C. \& Hoogerbrugge, A., 1990. Control of Prunus serotina in forests with the endemic fungus Chondrostereum purpureum. In: E.S. Delfosse (Ed.): Proceedings of the 7th International Symposium on Biological Control of Weeds, Rome, 1988. Ist. Sper. Patol. Veg. (MAF), pp. 545-552.

Spiers, A.G., 1985. Factors affecting basidiospore release by Chondrostereum purpureum in New Zealand. European Journal of Forest Pathology 15: 111-126.

Van der Werf, W., Rossing, W.A.H., De Jong, M.D., Mols, P.J.M. \& Rabbinge, R., 1989. Approaches to modelling the spatial dynamics of pests and diseases. In: R. Cavalloro \& V. Deluchi (Eds), Parasitis 88, Proceedings of a Scientific Congress, 25-28 October 1988, Barcelona, pp. 89-109.

Waggoner, P.E., Furnival, G.M. \& Reifsnyder, W.E., 1969. Simulation of the microclimate in a forest. Forestry Science 15: 37-45.

Ward, S.A., Wagenmakers, P.S. \& Rabbinge, R., 1989. Dispersal and dispersion in space. In: R. Rabbinge, S.A. Ward \& H.H. van Laar (Eds), Simulation and systems management in crop protection. Pudoc, Wageningen, pp. 99-118. 